\title{
First-year students' essay writing practices: Formative feedback and interim literacies
}

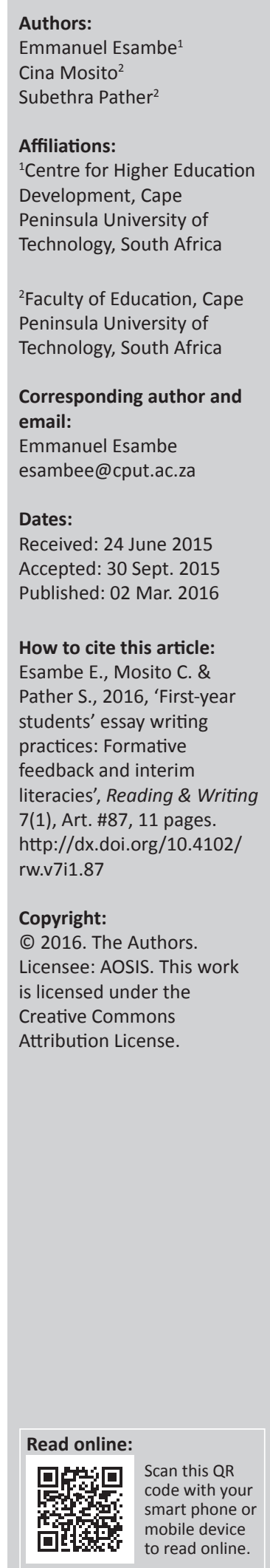

The varying literacy standards that undergraduate students represent are a reflection of their interim grasp of academic literacy (Paxton 2007). The aim of this study is to analyse a small group of undergraduate first-year students' depiction of their interim grasp of academic writing and to reflect on how lecturers use formative feedback to respond to specific issues regarding students' academic transitions within their discipline. Using an emancipatory methodology, this study was designed as a participatory action research. Qualitative data from focus group interviews with lecturers and photovoice presentations by first-year dental technology students were used to explore how students demonstrated their interim grasp of academic essay writing in a Health Science department at a university of technology. However, this article, which is part of a broader study, analyses a small class of first-year students' depiction of their interim grasp of essay writing and reflects on how their lecturers use formative feedback to respond to these students' academic transitions within their discipline. Using activity theory and morphogenetic realist theory to analyse essay writing activities during an intervention, the study reveals that images are potent artefacts that students and lecturers use to build meaningful dialogue during essay writing in an uneven terrain.

\section{Introduction}

The place of feedback in written assessments cannot be overemphasised. Several researchers have examined feedback in assessment practices from different perspectives (Clark 2012; Dornbrack \& Dixon 2014; Elton 2010; Mathew \& Sternberg 2009). Within these research papers is often a call for experts involved in the teaching of academic writing to contextualise their construction and dissemination of formative feedback such that it adequately supports student learning and retention (Clark 2012). In the same vein, there is also an urgent call for academic literacy experts to collaborate with discipline-specific lecturers in the construction of and dissemination of formative feedback during essay writing activities (Cauley \& McMillan 2010). Those who hold this view often argue that a first-year student is at a critical point of transition (in the context of learning how to cope with university education) and therefore needs to be taught the new ways of being and doing things from a contextual perspective (Dall'Alba \& Barnacle 2007). Paxton (2004) proposes the term interim literacies in an attempt to situate the typical first-year student's writing competencies within a transitional frame.

This article adds to the discussion on supporting first-year students in coping with university education by focusing on the use of formative feedback during essay writing practices in a Health Science discipline. The article explores undergraduate students' interactions with the formative feedback they receive from their lecturers during academic essay writing activities. Two categories of formative feedback emerged from the findings: one focusing on the students' writing and the other on the feedback strategies employed by the participants. The research findings suggest that the students' and lecturers' engagements with formative feedback reflect different levels of transitions; thus interim literacies is used as a concept to understand their current competencies.

\section{Literature and theoretical underpinning}

Academic writing in general and the ability of students to write an acceptable academic essay fall within the realm of academic literacies (Jacobs 2005; Lea \& Street 2006; Paxton 2007). Even though writing an academic essay is widely regarded as a 'high stakes' activity in tertiary education (Dornbrack \& Dixon 2014:1; Jacobs 2007:872), there is often insufficient support provided to students whose literacy competencies do not meet the requirements of the disciplines that they register in (McKenna 2010). Other researchers have pointed out that the instructions provided to students during essay writing activities are insufficient (Boughey 2008; Janks 2012). 
Still others think that there is insufficient integration of literacy courses ${ }^{1}$ into specialised disciplines (Carstens 2013; Shay 2008) or that there is insufficient collaboration between academic literacy practitioners and discipline experts (Jacobs 2005).

An alternative line of argument comes from those who see students' academic essays in higher education as representing an ontological stance (Barnett 2009; Dall'Alba \& Barnacle 2007). As McKenna points out, students are expected to 'write, talk, listen, and read in ways that conform to the dominant discourse of their practices' (2004:12). Different disciplines that these students register for require an awareness and appreciation of the 'customs and norms' that they should acquire to understand and communicate the knowledge of their disciplines (McKenna 2010:24). Winberg et al. (2010) explain that specialised disciplines such as Engineering and Health Sciences often require students' essays to meet specific requirements in terms of lexicon, grammar, textual organisations and social practices. They support the integration of literacy into the teaching of disciplinary subjects and the collaboration between literacy experts and discipline-specific subject lecturers as a suitable means of developing the student's being within a competitive higher education landscape.

This paper explores how the use of formative feedback by both students and their lecturers indicate that their current academic writing competencies can be better understood as interim. Formative feedback ${ }^{2}$ has been defined as feedback that is provided to a learner with a clear aim to 'show the learner where there are gaps and how to improve on the learner's work' (Bloxham \& Campbell 2010:291). Shute (2008:153) considers formative feedback as 'information communicated to the learner that is intended to modify his or her thinking or behaviour (in order) to improve learning'. This means that formative feedback should be understood within the discourse of formative assessment, or 'assessment for learning' (Asghar 2013:19; Gardner 2006:2). Pryor and Crossouard's broad view of the term formative highlights four key purposes: completing the task at hand, thinking about improvement, making sense of criteria and invoking learner identities (2010:266). Therefore, through formative feedback there is active learning interaction between the student and the lecturer with a clear intention to influence cognition (Black \& Wiliam 2009:11). Clark adds that this is suitable for a 'student-centered' learning activity (2012:205).

Formative feedback can be either synchronous, asynchronous, external or internal. The above types of feedback are described as formative because in all cases the student engages with a more knowledgeable other (MKO) with the desire to influence, change or improve cognition through that engagement (Black \& Wiliam 2009:11). Synchronous formative feedback is

\footnotetext{
1.The term academic literacy courses is used here to cover the wide spectrum of writing, reading, digital and information literacies that are offered in different modules across universities in South Africa.
}

2.I emphasise formative to distinguish it from other types of feedback such as summative. This article refers to the different types of formative feedback. feedback that is provided simultaneously as the student is actively engaged in the writing activity (Brophy 2004). During a writing activity, lecturers should create conducive spaces for synchronous formative feedback by using writing laboratories and providing immediate feedback on students' drafts while they write. This method creates qualities of spontaneity and dialogue during the writing activity (Black \& Wiliam 2009). The opposite of this method is asynchronous formative feedback. In this case, the lecturer waits for the students to complete a writing task before providing support and guidance (Clark 2012). The central difference between synchronous and asynchronous formative feedback is in the time difference between when the feedback is provided and when it is acted on. In the intervention reported in this article, we attempted to use both synchronous and asynchronous formative feedback. By doing this, we broke away from past practice in the department ${ }^{3}$ whereby only asynchronous formative feedback was provided to students by mainly writing centre staff when the students completed their essay assignments. Details of the intervention are provided later in this article.

The issue of time in the provision of formative feedback during writing is important. Therefore, in addition to synchronous and asynchronous formative feedback, there is ipsatic feedback, also referred to as feed forward. This method involves information of a specific nature being provided to students before they engage in a writing activity (Fisher \& Frey 2009). This sort of information includes writing instructions, rubrics and referrals.

The notion of interim literacies was introduced by Moragh Paxton as a means to understand students' struggles with undergraduate university writing assignments. Interim literacies is an emerging theme from her $\mathrm{PhD}$ research, which used linguistic and intertextual approaches to determine the connectedness between 'academic discourses and student voice' (Paxton 2007:45). Paxton coined the term interim literacies (2004) to represent an ideological look at first-year student writing competencies. With inspiration from the emerging discourses on academic literacies, Paxton (2012) made a contribution to our understanding of the transformations that occur through students' engagement with writing conventions. It should be noted here that other researchers had highlighted issues around learning and the contestations of meaning between students and lecturers and how this leads to transformation (Canagarajah 2002; Clark \& Ivanic 1997). With interim literacies, the student is situated within a period whereby they navigate the gap between pre-university education and their current university expectations.

In order to understand how the use of formative feedback during essay writing practices reflects first-year students' interim literacies, we draw on two theories to interpret our data: activity theory and critical realism. Activity theory breaks away from constructivist theories in order to 3.Department refers to the Department of Dental Sciences, where the intervention reported in this article took place. 
highlight the role of praxis 'in a material and social world' (Wheelahan 2007:191). We borrow from Engeström's (1999a) depiction of an activity system to explain how students and lecturers interact with different types of formative feedback and observe specific roles and rules within a clearly defined setting, in order to achieve improved essay writing skills. Using this theory, we underline some of the inherent challenges or contradictions (tensions) within an activity system and explain how these contradictions can contribute to 'change and innovation' (Engeström \& Miettinen 1999:9) or transformation within the system.

We also use critical realism [with emphasis on Archer's (1995) morphogenetic realist social theory] to explain the ontological stance that students assume when engaging with formative feedback during essay writing practices and how this stance affects the object of the activity. Archer's morphogenetic realist social theory is framed from the broader philosophy of critical realism, which according to Sayer (2000:78) is an 'umbrella philosophy with a strong focus on ontology, not epistemology'. Archer emphasises this distinction when she states that critical realism as a philosophy bears affordances for social theory because it's ontological strengths '[act] as both gatekeepers and bouncers for methodology' (1995:22). The major premise in Archer's morphogenetic realist theory is her conception of the morphogenetic cycle (Archer 1995). In it, Archer discusses the differences between agents and the social structures in which agents act. She indicates that the structures refer to previous interactions with agents and that this influences the ways in which new agents adapt to the new settings (Archer 2003). In the intervention reported in this study, spaces like the writing centre, the library and the classrooms are existing structures within the Department of Dental Technology. The agents within these structures are the lecturers, the academic support staff (academic literacy lecturers and writing consultants) and the students. The intense collaboration between specific students and their lecturers during the essay writing workshops is analysed using Archer's morphogenetic cycle to represent agents acting on structures.

One commentator sees critical realists as people who interpret the social structures in terms of 'systems of human relations among social positions' rather than as individual responsibilities that should inform human activities (Porpora 1998:339). This view highlights some of the areas where critical realism can complement activity theory. Both theories analyse societies in abstract and descriptive terms (Wheelahan 2007). They are both opposed to positivism and the desire to isolate variables in order to understand our world (Sayer 2000; Tolman 1999). Both theories have strong roots in Marxism. To this regard, critical realism allows for the conceptualisation of the role of the self, whereas activity theory allows for the description of the self (Wheelahan 2007). This is how the individual student or lecturer (the self) relates to other staff and students in the department (the community). This shows the mutually explanatory energy of both theories. The students, the lecturers and the writing centre staff individually have different definitions of who they are within the academic set-up in the Department of Dental Sciences. Before this intervention, they were interacting with each other in a way that did not adequately improve the students' learning of essay writing. During the intervention, the individuals through collaboration with each other developed new ways of defining themselves within the community, as well as their individual roles in the teaching and learning of essay writing skills.

\section{Rationale for study}

The studies on formative feedback and writing practices cited above have focused mainly on the students' essay writing skills and how such skills can be adapted to meet the expectations of their academic programme. The majority of these studies have explored different methods of providing feedback and have typically identified the student as a learner in transition, especially within the context of their programmes in particular and their universities in general. This study focuses on the relationship between the student and the writing activity as rules influenced and developmental and explores how the context of the students' academic programme influences the interaction with formative feedback between the students and the lecturers. The notion of interim literacy is defined as the state of transition in a student's literacy practices within their context of learning. Activity theory and Archer's morphogenetic realist theory are employed to probe how engagement with formative feedback by both students and lecturers lead to certain types of transformations for them.

\section{Research methodology}

This study makes use of participatory action research ${ }^{4}$, which resides within the social constructivism approach in qualitative studies. This approach allows 'subjective meanings of people's experiences' and directs them towards specific objects or things (Creswell 1997:8). Such meanings are manifested and realised socially and historically (Makoelle 2012). Galtung (1975:273), for example, encourages this kind of research when he indicates that researchers should consider conducting non-violent social research that abdicates from doing research 'on people', in favour of doing research ' $w i t h^{5 \prime}$ people. This study is therefore situated within the 'participatory advocacy' worldview (Creswell 1997:8; Neuman 2000:32), whereby the researchers immense themselves in the activities with the participants for the purposes of achieving social or ideological change.

The data for this article were sourced from a larger qualitative emancipatory action research project whose aim was to explore the design of academic literacies interventions for first-year students at a science faculty in a university of technology (UoT). Qualitative action research is supported

\footnotetext{
4.Participatory action research (PAR) distinguishes itself from collaborative action rearch in that in PAR, the researcher is coparticipant and does not lead the research process. Rather, the team (researcher and participants) jointly decide on research process. Rather, the team (researcher
the way forward for the research (Swantz, 2008).
}

5.Italics in original. 
by researchers who posit that action research is ideal as a 'critical praxis' in the field of education (Cohen, Manion \& Morrison 2007:301; Makoelle 2010:36). It was adopted as a methodological framework in this research because at the heart of the research was the desire to see students who were involved in various collaborative learning projects enhance their use of formative feedback during essay writing.

Data reported in this article were collected from first-year students in the Department of Dental Sciences at a UoT. The class consisted of a small group of students (13) and four lecturers. For this project, three out of the four lecturers were conveniently sampled to participate in the study. All 13 students agreed to participate in the project. Participation of lecturers and students for this study was on a voluntary basis. The participants all completed a consent form and attended orientation sessions before participating in the study.

Cohen et al. (2007) warn that in action research, as employed in this study, ethical issues can arise because of the nature of the problem being reported and the tools used to collect valid data. Therefore, it was necessary to conduct an orientation session with all the lecturers and students who participated in the research in order to clarify all the possible ethical issues that this research posed, as well as to adopt an open and democratic approach towards solving those issues. This was in addition to observing the university's protocol on ethics during research, such as obtaining authorisations, informed consent and the protection of participants' identities.

Three instruments were used to collect data: focus group interviews, photovoice $^{6}$ presentations and document analysis. Focus group interviews were used to elicit deep responses from the three lecturers, with the focus of the interview being on the lecturers' design and use of formative feedback during an essay writing activity. Photovoice presentation was used as it was an effective and suitable tool through which the students could articulate their experiences with formative feedback as they engaged with the writing activity. This was a suitable tool for this emancipatory ${ }^{7}$ research because the power of images allowed the participants to be more articulate about their writing experiences. Finally, in order to strike a balance between the often divergent voices of the students and lecturers as participants, we extracted data from selected documents that informed the participants' engagements with formative feedback. These documents included extracts from the students' draft essays, extracts from actual feedback that the lecturers provided, extracts from rubrics and assignment instructions.

\section{Summary of the intervention}

The three lecturers involved in this project assigned three different essay topics to be completed by the first-year group

6.A photovoice presentation is a visually intensive approach to collect data "in which the presenter uses photographs to tell a story' (Esambe 2015:51). The presenter does not aleys describgrat does not always describe what is visually captured in the images, but seeks to evoke 'deep interpretations' by narrating the 'symbolic' and/or historical significance that
the pictures capture (Kuratani \& Lai 2011:13).

7.Emancipatory research is defined as any 'research that seeks to empower the subjects of social inquiry' (Letherby, 2006:89). Therefore, PAR is emancipatory research. at different intervals between February and September 2014. We (the authors of this article) were invited by these lecturers to provide writing skills to the first-year students through individual student consultations. Because we had provided one-on-one consultations with past students in the writing centre, we requested a planning meeting with these lecturers in order to properly plan this intervention. During our planning discussions with the lecturers, we realised that the lecturers' proposed strategy of providing formative feedback to the students was framed from the discourse of the autonomous text (i.e. full meaning is contained in the writings provided by the lecturers). We therefore proposed a participatory model to support these first-year students through their essay writing assignments. This model involved the lecturers, the students and the academic literacy staff providing formative feedback collaboratively at various stages of the writing process. We organised a number of workshops in which we collaborated with the three lecturers in the provision of formative feedback to the students. Before we started the intervention, we had a focus group interview with the lecturers in order to identify their perceptions of the students' essay writing and their areas of concern. We also had a focus group interview with the three lecturers after the intervention in order to discuss the impact of the intervention and to plan how to improve support for the students in 2015. The students were each asked to do two photovoice presentations, the first before the intervention and the second after the intervention. In these presentations, we asked the students to explore first their challenges in completing the essay assignments and, later, their experiences during the interventions.

Pseudonyms were used to ensure confidentiality of the participants; in addition, the participants' faces were blurred in the photographs used. No marks were allocated during the workshops; rather, we provided writing support (grammar, sentence structure, paragraph development, argument and voice) and the three lecturers provided content support (details, examples, illustrations and relevance). The students were given time to revise their drafts and to discuss their revisions during the workshops. This strategy allowed us to provide formative feedback synchronously and asynchronously. The topics of the essay assignments were set by the lecturers, and we collaborated with them in revising their rubrics for the essays.

\section{Data analysis}

We extracted two categories of formative feedback from the data in this study. The first category was the formative feedback provided by us and the three lecturers to the students during the completion of their essay assignments. Such feedback was provided at different stages of the draftrevision process. The second category of formative feedback focused on the strategies used during this intervention. It explored the three lecturers' and the first-year students' perceptions of the draft-revision process, the dialogue that ensued during the workshops and the use of photovoice to capture their experiences of the intervention. 
Using the basic structure of an activity system, the data were coded in terms of the six categories of an activity system: subject, tool, rules, community, division of labour and object. This coding was aimed at illustrating how the students' writing, serving as subject, was improved through contact with specific artefacts represented by the different types of formative feedback that was provided. In Engeström's (1999b) model of an activity system, the artefacts represent the tools that the subject engages with in order to achieve a desired goal or object. In this study, the rules refer to those guidelines that students and lecturers work with during an academic engagement, such as essay writing. This includes explicit rules such as assessment guidelines and implicit rules such as those governing the relationship between student and lecturer. The community is made up of the lecturers, the students and literacies support (from the writing centre, library and science laboratories). The roles, also known as division of labour, refers to the tasks assigned to different members of the community during the activity. Hassan (2013:202) indicates that there are 'horizontal' and 'vertical' roles, which are inspired by the Marxist heritage that activity theory borrows and which contributes to the power relations within an activity system. An adaptation of Engeström's version of an activity system is presented in Figure 1.

Building from activity theory, the data were further scrutinised in terms of Archer's morphogenetic cycle, particularly her rendition of the role of the self in collective activities. We examined how the students negotiated the completion of their essay assignments with the help of formative feedback from several sources, and we attempted to determine how these engagements and experiences impacted on how the students identified themselves. Archer (2007:36) refers to this as the 'subjective ontology' and explains that it relates to the sharing between a writer and their author as an epistemic outcome. The students' essay writing needs are therefore interpreted to represent a strong call for society (lecturers, faculty administration and academic support staff) to rethink how they design strategies

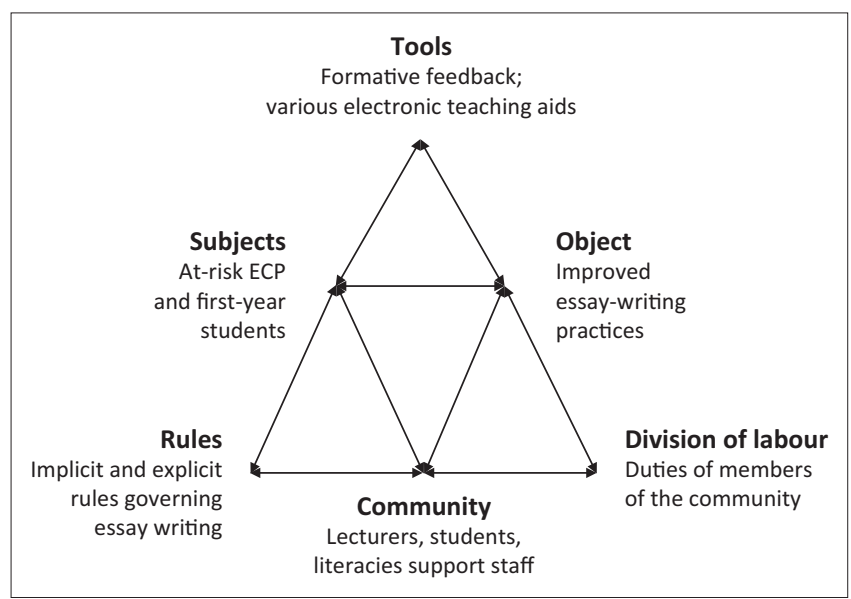

Source: Adapted from Engeström, Y., 1999a, 'Activity theory and individual and socia transformation', in Y. Engeström et al. (eds.), Perspectives on activity theory, pp. 19-38, Cambridge University Press, Cambridge.

FIGURE 1: A model of an activity system. intended to support first-year students in coping with the rigours of university education. In this case, 'society is both the condition and outcome of human agency' (Bhaskar 1998:xvi). The deficit approaches previously employed, whereby the students were tasked by their lecturers to undergo essay writing lessons that were out of sync with their disciplinary expectations, are challenged.

\section{Results/findings}

The findings section reports on the intervention that was initiated whereby formative feedback was used as a tool through which to achieve the goal of improved essay writing skills. The focus of the analysis, however, is on the tensions that emerged through the research participants' changing views of themselves and their academic writing practices within their discipline and how this represents their interim literacies. Using an activity system, we focus on the interaction between the subjects, tools and object and explore how the changing identities of who the subjects are re-enforces the notion of interim literacies.

\section{Lost in transition 1: Tensions between students' prior discourses and current institutional expectations}

According to Engeström (1999b) the subject in an activity system is an individual or group of people who are acting on an object. In this section, we explore how the students, acting as subjects within an activity system, arrive at the university with attributes that the lecturers interpret as posing challenges to the system. Such attributes include their writing style, reading skills and oral traditions that they learned through high school. These challenges serve as tensions within the activity system.

The students' descriptions of their interaction with the formative feedback being provided by their lecturers during essay writing highlight strong tensions relating to their perceptions of their writing competencies. The students felt that they were already competent enough to cope with the demands of university writing, because of their prior school learning. During the photovoice presentation, 'Diane ${ }^{\prime 8}$ noted the following:

'I studied in English in high school; and my grades were great! I really don't mind being taught in English. I watch a lot of movies in English and it is not a problem. I also speak to a lot of people outside in English even though at home we use Afrikaans. When I was working, we used mostly English at work; so I think I'm sorted. But the lecturers don't think so'. (Diane, 2014)

Another student, Pierre, raised similar issues to Diane as seen below. Pierre's assumptions were similar to Diane's even though they were from very different backgrounds:

'At first, I wasn't scared of studying here even though I'm from France and my first language is French. When we got here, I was the first to make friends with the guys around our house and I hang out with them pretty much. However, in varsity, even though I understand the lecturers when they speak, I still fight

8.All the participants' names used in this paper are pseudonyms. Their real names are not used for purposes of anonymity. 
with them in my essay assignments. They are always moaning about my style and the words I use in my essay. But these are words we all use all the time! They don't want me to write and be me when I write [authors' emphasis]. I can't just copy and paste stuff; this is now hard to write for me ...' (Pierre 2014)

From Diane and Pierre's quotes above, the main tension emerging is that of the student transitioning from their high school ways of writing to university expectations of their writing. Diane assumed that she was a competent user of English; she was thus worried why the lecturers did not think so. Pierre saw the feedback interaction with the lecturers as constituting a 'fight', through which the lecturers attempted to deprive him of his identity. He said, 'They don't want me to write and be me when I write'. This means that he saw the lecturers' feedback as texts that represented animosity. Borrowing from Boughey (2008) we interpret Pierre's and Diane's statements above to represent their challenge of the lecturers' word as an autonomous text. We shall explain why this is so later in this article.

Another student, Sonwabo, puts this conflict in transition more succinctly when he says:

'When I first got my essay instructions and brief, I felt lost. It was difficult. I just couldn't tell what exactly they wanted me to do. Then I wrote my first draft which looked funny, it was only my introductions and part of my body, and I gave it to the lecturer. I thought that he would tell me how to make it right, but what he wrote on my draft made me more confuse. I felt so bad I wanted to leave the course, [long pause] almost'. (Sonwabo 2014)

Sonwabo's confusion above is supported by a picture from his photovoice presentation as seen in Figure 2.
The gap between the students' prior academic discourse and current university expectations highlights the issue of transitions for first-year students. It is, however, very telling that the students are grappling with these tensions, internalising them and making meaningful reflections around the issues affecting their writing. This view contradicts the assumption often publicised that first year students' literacy challenges are caused by their inability to appreciate their current academic setting and/or community. In this regard, Sonwabo's picture above reinforces his belief that his current challenges are but temporary and that even though he has not mastered the expected ways of writing in dental sciences, he does bring with him some moral capital needed to negotiate such challenges. He says: 'I felt so bad that I wanted to leave the course, almost'. He said 'almost' after a long pause, in a way showing his ability to persist in this difficult new terrain. This confirms his current writing competencies as interim, situated between his high school writing skills and the projected learning requirements he is being initiated into.

\section{Lost in transition 2: Tensions between students' definitions of being and disciplinary expectations}

Rules play a major role in regulating the interaction between subjects and their tools within a community (Engeström 1999b; Hardman 2005). From this perspective, the gap between the students' prior academic writing skills (learned in high school) and the current academic expectations are heavily influenced by the rules. Another student, Mbali, used a picture to make this claim very powerful (Figure 3).

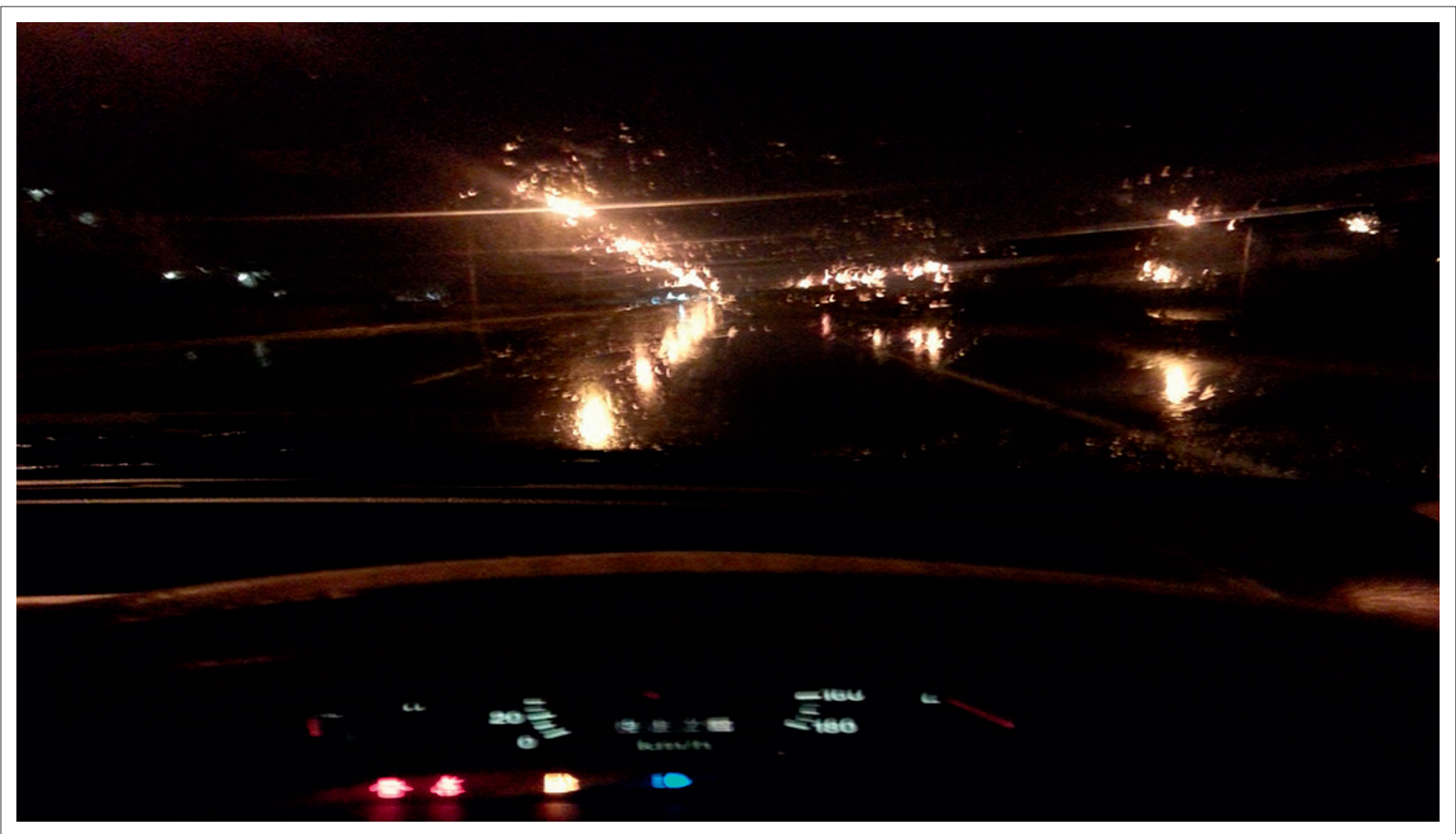

FIGURE 2: Sonwabo's picture of poor visual conditions on the road. 


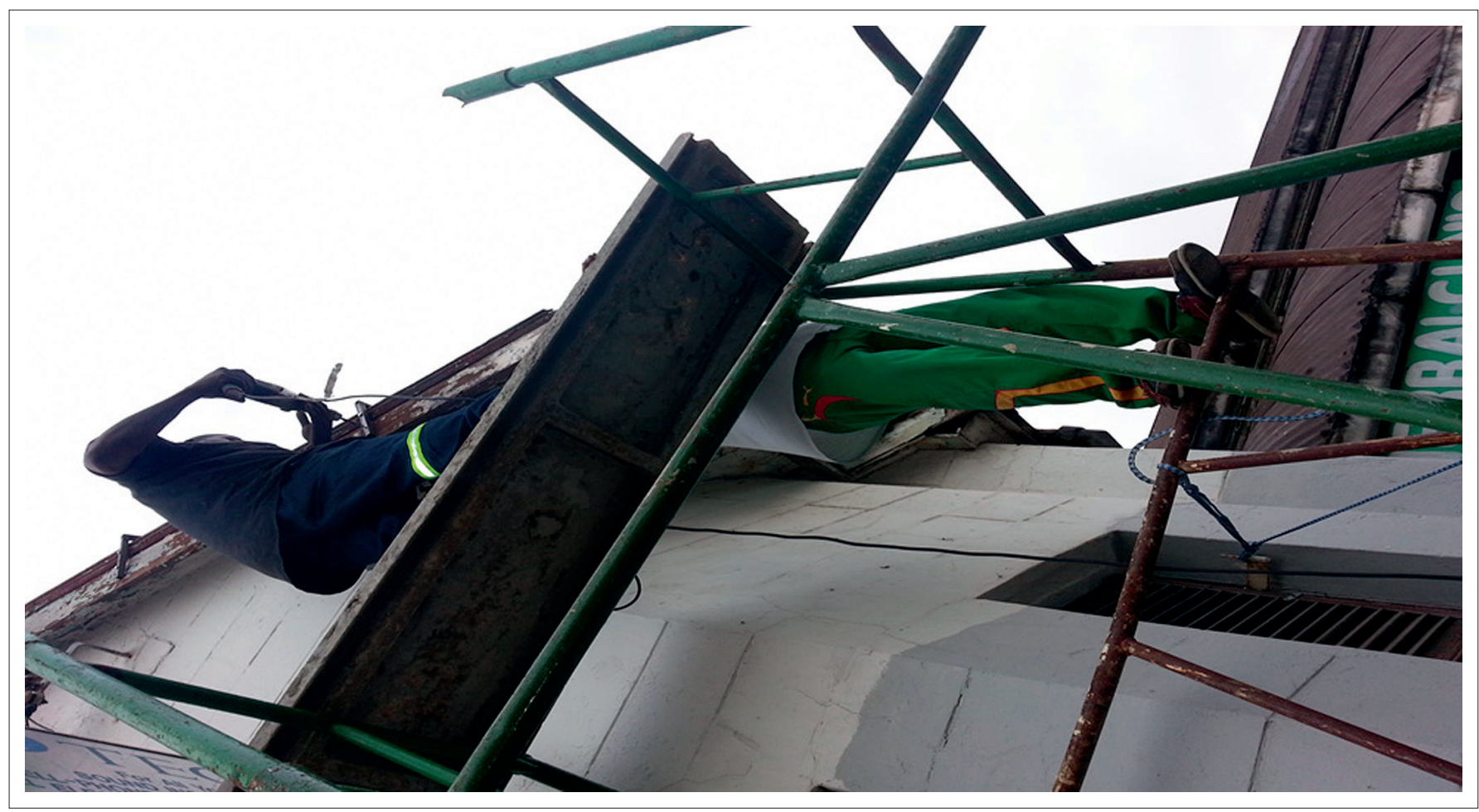

FIGURE 3: Mbali's picture of her father at work

In her narrative, she explained:

I was attracted to Dental Technology because I wanted to work with my hands. Even though I am a girl, my daddy always told me that I was gifted and I can make anything I want. Because he own a small metal workshop, I used to always go there and help. It was easy: you just have to be very careful with the machines; and to be always alert and awake when working with them; and you can make anything you wanted like iron gates and roof plates. Anything. He doesn't use fancy equipment, and he doesn't really protect himself. I can say that now because in Dental Technology, the rules are very strict: they watch what you wear from head to toe! It has taken me some time to get used to all these instructions and rules. Worst part is when I go home on holidays; I can't work well with my daddy at his shop because he says I am no longer at his level. (Mbali 2014)

There is a difference between informal artisanal trade and very established vocational industries. Artisanal practices like the small informal shop where Mbali acquired her passion for a vocational discipline is different from a formal, rule driven and professionally oriented setting such as a university's dental technology laboratory as described in her narrative. Some of these rules, such as those outlining health and safety within the laboratory, are very explicit, whilst some are only implied. For example, Pierre could not understand why his lecturer expected him to use correct referencing and discipline-appropriate vocabulary in Figure 4.

The picture below from Pierre highlights some of the implicit writing rules that his lecturer expects him to be aware of. For purposes of illustration, we quote verbatim some of the comments from the lecturer as contained in Figure 4:

- 'You may need to define and identify the different muscles of mastication first' (comment at the top left of the page).
- 'Format: Align all your text to the far left. Headings and sub-headings; as well as illustrations should be numbered appropriately' (top right of page).

- 'Provide the necessary in-text references' (middle left of page).

The excerpts of the lecturer's formative feedback quoted above from the student's (Pierre's) draft are intended to direct Pierre to some of the implicit rules of essay writing at the undergraduate level. Rules relating to writing style, textual organisation, formatting and choice of words, for example, are implicitly conveyed together with an assignment task. All three lecturers in this case assumed that their students were conscious of these rules. However, the level to which the students were conscious of these rules, whether explicit or implicit, was very different from what the lecturers expected. This raised tensions relating to how the students perceived themselves within their disciplines; as well as how their lecturers perceived them. The absence of oral dialogue between the lecturer and the student during the completion of the essay assignment contributed to the students' difficulty in understanding the lecturers' formative feedback. Without adequate formative feedback support and appropriate strategies in delivering such feedback, the student were left helpless as captured by this despairing comment from Pierre: 'They don't want me to write and be me when I write. I can't just copy and paste stuff; this is now hard to write for me ...' (Pierre, 2014).

\section{Lost in transition 3: Tensions between lecturers' assumptions of students' learning needs}

In an academic environment where knowledge is considered as the ability to contest meaning from different points of view, the role of formative feedback is very important in 


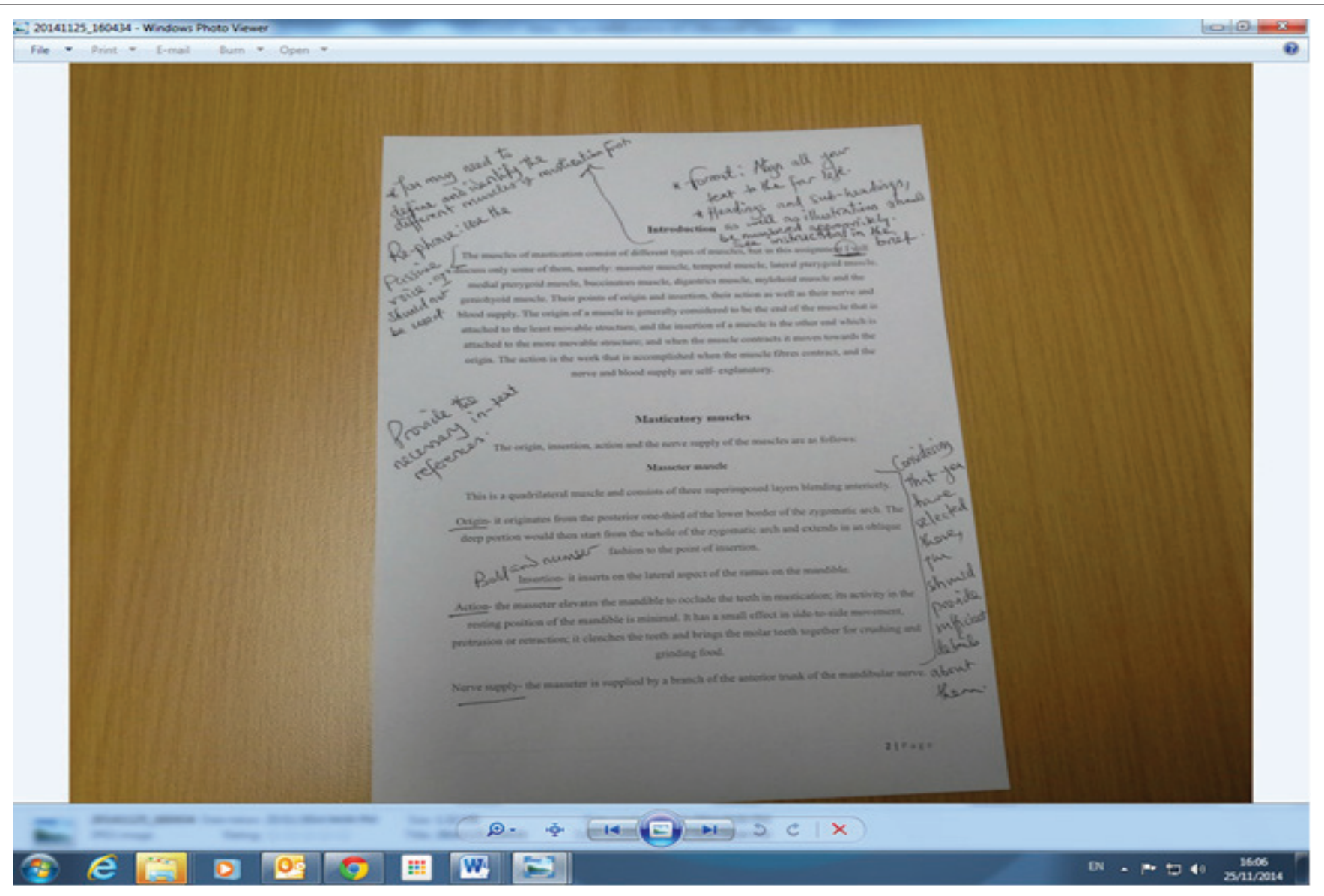

FIGURE 4: Implicit and explicit writing rules highlighted through formative feedback.

guiding undergraduate students to develop this attribute. The zone of proximal development has been defined as 'the distance between the actual developmental level as determined by independent problem solving and the level of potential development as determined through adult guidance' (Vygotsky 1978:86). The ability of a lecturer to spot a learning gap and provide apt formative feedback that propels the student towards knowledge achievement is crucial in bridging the gap in the zone of proximal development. However, findings from this research suggest that some students perceive some lecturers as struggling to provide the right formative feedback through the right medium and at the right time to the students; and that this affects the way the student interprets the formative feedback. Diane alleged that:

'I feel bad that the lecturers were not always there to assist us like they assisted the ECP group of students. They asked us to submit our drafts for feedback, and they wrote the feedback on them, but did not explain what the feedback meant. Many times, what they wrote was just to ask us to refer to our notebook or textbook. Sometime, it was worse; they will just write a question mark, or say 'what is this' on your draft. How does that help me to know what the lecturer wants me to know?' (Diane 2014)

The way students enact language competencies during literacies activities should be a valuable means for lecturers to examine their own practices (Katiya, Mtonjeni \& SefalaneNkohla 2015). Diane's narrative above demonstrates that the lecturers might not have given much consideration to the strength of their feedback. Diane's allegation above has been accepted by one of the lecturers who participated in this study. One lecturer commented as follows:

I expect them to attend my lectures and to attend the workshops that are organised in conjunction with the Writing Centre. I also expect them to bring along drafts of their essay during the workshop. Those who don't come with their drafts are sent back home and marked absent. I expect them to contribute during the workshops, and to express themselves in a manner that I can understand. As the year progresses, I expect them to be able to express themselves in a proper academic manner. I penalise them if they don't use the right dental terminology when writing; and I also penalise them when they don't express themselves as professionals [our emphasis]. (Ms Lynnette ${ }^{9} 2014$ )

Another lecturer, Mr Frings, asked the following questions:

'What did these students learn in high school? They can't write, they can't read, they can't communicate. When we were in school, did we have fancy services like the writing centre? Why don't they want to make use of the writing centre? Why must I drag them there? Do they even know that this is a university?' (Mr Frings 2014)

The above extracts from the lecturers represent a classic case of lecturers foregrounding the rules to the detriment of learning. These lecturers, in their own words, confirm the 9.Lecturers' real names have been hidden to protect their identities. 
students' allegations that some of their lecturers 'just assume that the students already know stuff, and we must then write in a particular way already' (Sonwabo 2014). For a discipline like dental sciences, it is necessary for the lecturer, as the $\mathrm{MKO}$, to demonstrate awareness that some students might need a longer time to master the discipline's terminologies and professional ways of expression. This realisation, arrived at by the lecturers during the completion of this project, confirms how they negotiate their own transition, as well as the fact that they are also at an interim state in their use of formative feedback

\section{Discussion}

Some first-year university students in the post-apartheid South African context, placed as subjects within an activity system, struggle to identify themselves within the institution as a whole and within their chosen discipline in particular. These students are constrained by the new rules of the game, and this often provokes tensions within the system. Figure $5 \mathrm{a}$ maps the main activity system whilst Figure 5b highlights where there is current tension caused by transition.

Change is often difficult to achieve. Enforced transition, caused by the need to apply the explicit and implicit rules of the university; as well as those of the discipline, leads to tension within the activity system. This tension is also reflected in the way the students interact with formative feedback as they seek to negotiate their literacies awareness in their new learning contexts.

A realist social theory depicts a socio-ontological stance in which physical things, human beings and their expressions, as well as the settings in which they operate, are seen as social constructs arising out of processes and connections (Fairclough 2005; Harvey 1996). The subject in the above activity system (Figure $5 \mathrm{~b}$ ) is seen as a student in transition. Placed within an ideological gaze, such a student is seen to be in a state of flux and exhibits qualities that indicate that they are partially conscious of their identity, as well as not being too sure of the new identities that they will take on as they progress within their discipline.

Our interest in this article has been twofold: to analyse how a small group of first-year students depict their interim grasp of essay writing, as well as to explore how a collaborative, formative feedback intervention enables students and lecturers to have meaningful dialogue during the completion of essay assignments. One of the lecturers noted as follows:

'We assume that our students who come here are the same; and that they have the same set of skills and competencies. My reflection during this project has shown me otherwise. Some of these students come from very difficult backgrounds, and the way they have managed to persist despite their own challenges is revealing. Inow see that I have been a bit lazy to not always go deeper and know my students more. This is a real revelation for me.' (Ms Antoinette, 2014)

Lecturers in a health science discipline such as Dental Sciences might not be expected to have the skills to teach or assess language (Klein \& Aller 2008), but they are expected to at least mediate in the students' development of their rhetorical stance (Dornbrack \& Dixon 2014). It is this realisation that puts the students' (and sometimes, 'lecturers') literacies practices within the gaze of interim literacies.

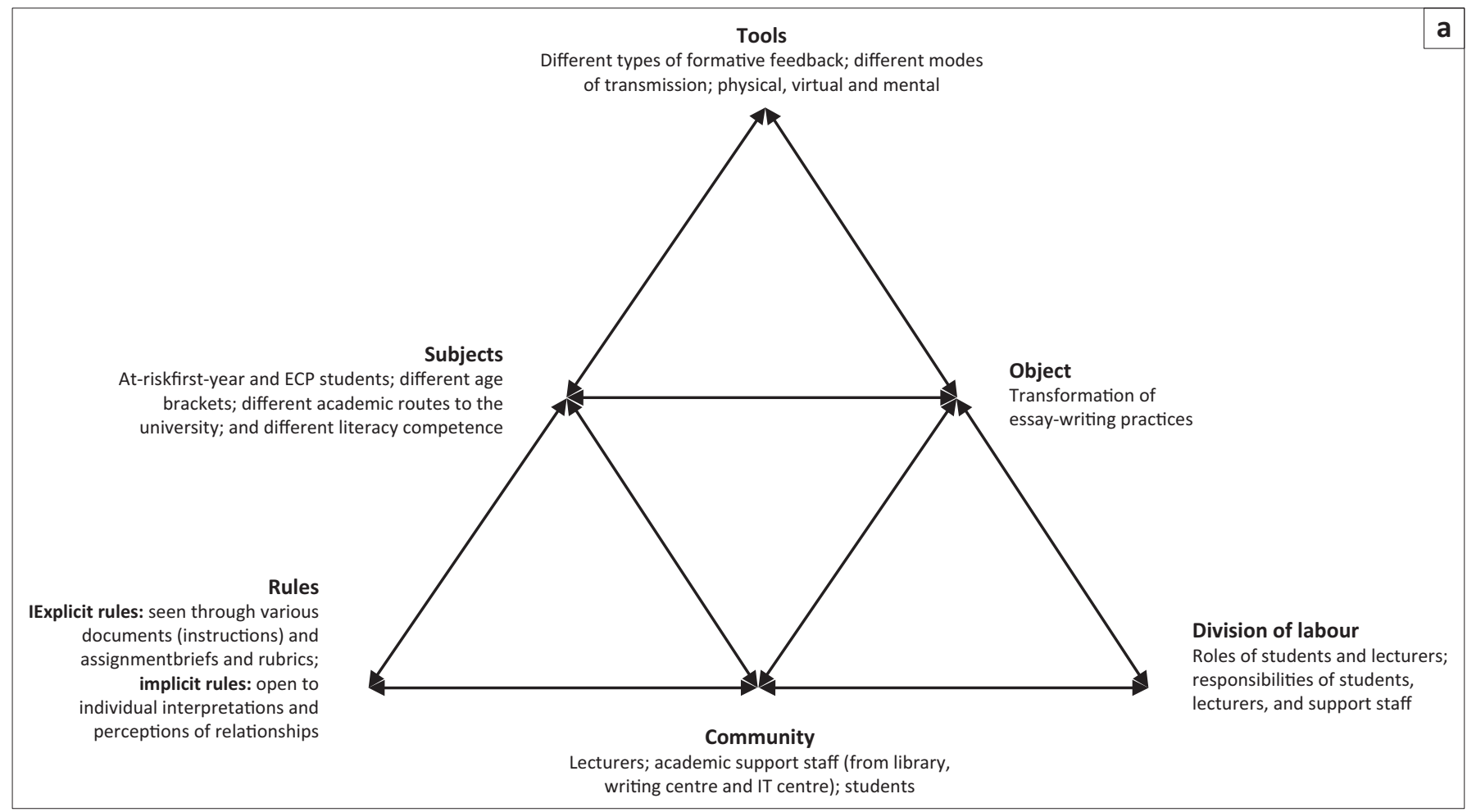

FIGURE 5: (a) The main activity system; (b) Section of activity system where transition causes tension. 


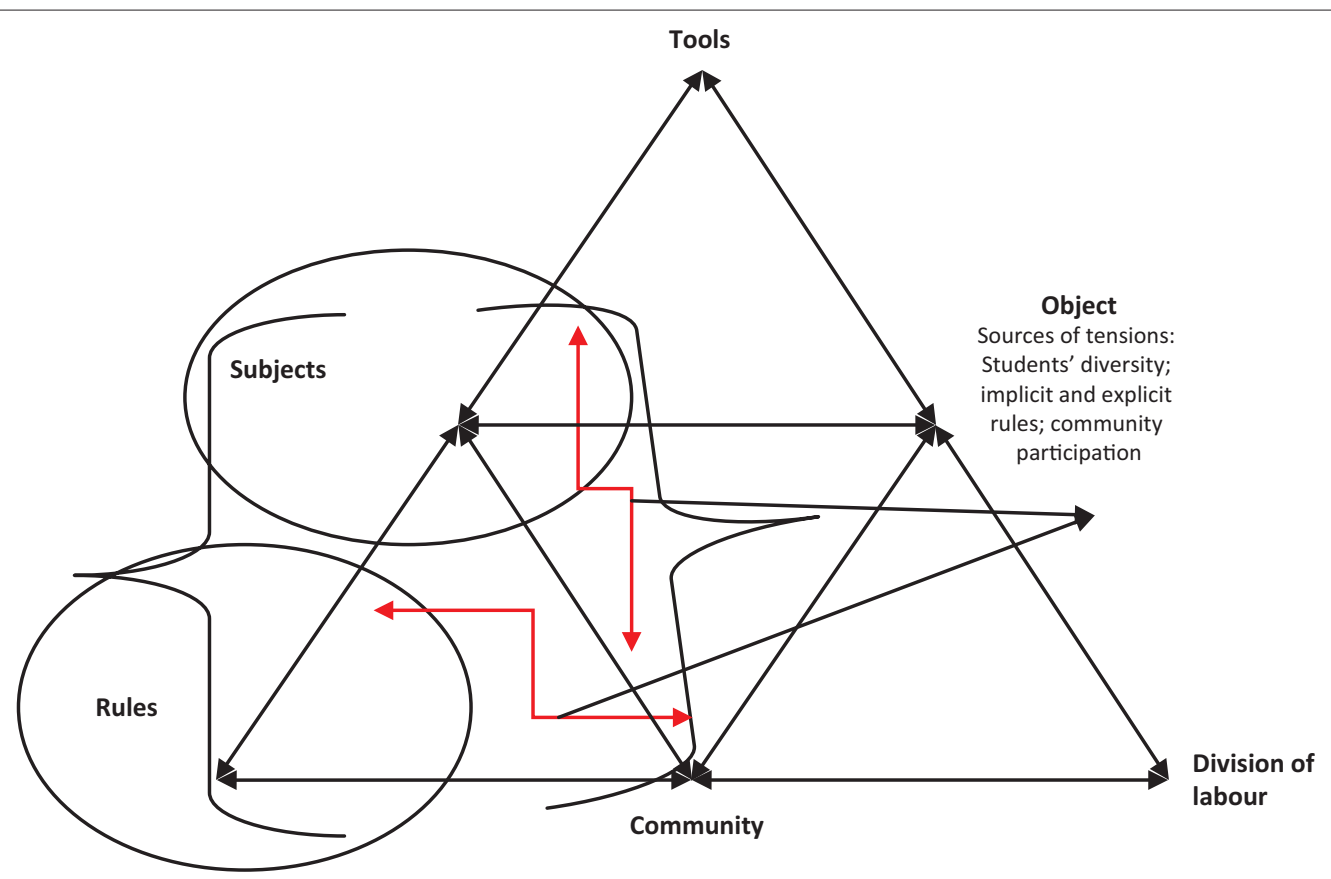

FIGURE 5 (Continues...): (a) The main activity system; (b) Section of activity system where transition causes tension.

\section{Conclusion and implications}

Data from this research suggest that both the students and sometimes the lecturers are in a state of flux in terms of their literacies practices and that their engagements with formative feedback during essay writing practices demonstrate their interim literacies. Using activity theory as an analytical tool, we identified some of the tensions that emerge when the students and lecturers use formative feedback during writing practices. Tensions posed by institutional contexts, disciplinary requirements and lecturers' assumptions have contributed in constraining the effective use of formative feedback during essay writing practices. There is a gap between students' current writing competencies and the required competencies from a disciplinary and institutional context. There is also a gap between the lecturers' perception of their formative feedback provided to the students and the actual interpretation of the feedback by the students. These gaps demonstrate why we see the students and lecturers literacies practices as interim.

Archer's morphogenetic cycle was a suitable lens used to probe the roles and actions of the students and lecturers and re-examine the tensions that emerge due to their own assumptions within a system. We noted that within a community like the department of Dental Sciences, certain structures such as the writing centre exist, and lecturers, students and the formative feedback they use are agents acting on the structures. The relationship between the lecturers and students and the support services such as the writing centre evoke attributes that contribute to defining their identities. As such, their realisations of the challenges that they experience whilst engaging with formative feedback serve as enablers that propel them to seek solutions and improve on their practices. This realisation transforms the way the students and lecturers perceive formative feedback and above all how they define themselves within the system.

\section{Acknowledgements}

We would like to acknowledge the pedagogic support provided during the Scholarship of Teaching and Learning Project at the Cape Peninsula University of Technology. Sincere appreciation is extended to Professor Christine Winberg; Associate Professors Solachan Hassan and James Garraway. Mrs Najwa Noorodien-Fataar's support as mentor is also acknowledged. A special word of thanks to the two anonymous reviewers for providing some very insightful feedback. Their advice and criticism went a long way in shaping this article.

\section{Competing interests}

The authors declare that they have no financial or personal relationships that may have inappropriately influenced them in writing this article.

\section{Authors' contributions}

E.E. (Cape Peninsula University of Technology), and C.M. (Cape Peninsula University of Technology) and S.P. (Cape Peninsula University of Technology) contributed equally to the writing of this article.

\section{References}

Archer, M., 1995, Realist social theory: The morphogenetic approach, Cambridge University Press, Cambridge. http://dx.doi.org/10.1017/CBO9780511557675

Archer, M., 2003, Structure, agency and the internal conversations, Cambridge University Press, Cambridge. http://dx.doi.org/10.1017/CBO9781139087315

Archer, M., 2007, 'The trajectory of the morphogenetic approach: an account in the first person', Sociologia, Problemas E Practicas 54, 35-47.

Asghar, M., 2013, 'Exploring formative assessment using cultural historical activity theory', Turkish Online Journal of Qualitative Inquiry 4(2), 18-32.

Barnett, R., 2009, 'Knowing and becoming in higher education curriculum', Studies in Higher Education 34(4), 429-440. http://dx.doi.org/10.1080/ 03075070902771978 
Bhaskar, R., 1998, 'General introduction', in M. Archer et al. (eds.), Critical realism: Essential readings, pp. ix-xxiv, Routledge, London.

Black, P. \& Wiliam, D., 2009, 'Developing the theory of formative assessment', Educational Assessment, Evaluation and Accountability 21(1), 5-31. http://dx.dol. org/10.1007/s11092-008-9068-5

Bloxham, S. \& Campbell, L., 2010, 'Generating dialogue in assessment feedback: Exploring the use of interactive cover sheets', Assessment and Evaluation in HigherEducation 35(3), 291-300. http://dx.doi.org/10.1080/02602931003650045

Boughey, C., 2008, 'Texts, practices and student learning: A view from the South' International Journal of Educational Research 47, 192-199. http://dx.doi. org/10.1016/j.ijer.2008.01.007

Brophy, J., 2004, Motivating students to learn, 2nd edn., Lawrence Erlbaum, New York.

Canagarajah, S., 2002, Critical academic writing and multilingual students, University of Michigan Press, Ann Arbor.

Carstens, A., 2013, 'Collaboration as the key to integration of language and content in academic literacy intervention', South African Journal for Language Teaching 47(2), 109-126. http://dx.doi.org/10.4314/jlt.v47i2.6

Cauley, M. \& McMillan, J., 2010, 'FA techniques to support student motivation and achievement', Clearing House: A Journal of Educational Strategies, Issues and Ideas 83(1), 1-49. http://dx.doi.org/10.1080/00098650903267784

Clark, I., 2012, 'Formative assessment: Assessment is for self-regulated learning', Education Psychology Review 24, 205-246. http://dx.doi.org/10.1007/s10648 011-9191-6

Clark, R. \& Ivanic, R., 1997, The politics of writing, Routledge, London.

Cohen, L., Manion, L. \& Morrison, K., 2007, Research methods in education, Routledge, New York.

Creswell, J.W., 1997, Qualitative inquiry and research design: Choosing among five traditions, Sage, Thousand Oaks.

Dall'Alba, G. \& Barnacle, R., 2007, An ontological turn for higher education', Studies in HigherEducation 32(6), 679-691. http://dx.doi.org/10.1080/03075070701685130

Dornbrack, J. \& Dixon, K., 2014, 'Towards a more explicit writing pedagogy: The complexity of teaching argumentative writing', Reading \& Writing 5(1), Art \#40, 8 pages. http://dx.doi.org/10.4102/rw.v5i1.40

Elton, L., 2010, 'Academic writing and tacit knowledge', Teaching in Higher Education 15(2), 151-160.

Engeström, Y., 1999a, 'Activity theory and individual and social transformation', in Y. Engeström et al. (eds.), Perspectives on activity theory, pp. 19-38, Cambridge University Press, Cambridge. http://dx.doi.org/10.1017/CBO9780511812774.003

Engeström, Y., 1999b, 'Innovative learning in work teams: Analysing cycles of knowledge creation in practice, in Y. Engeström et al. (eds.), Perspectives on activity theory, pp. 377-404, Cambridge University Press, Cambridge. http://dx. doi.org/10.1017/CBO9780511812774.025

Engeström, Y. \& Miettinen, R., 1999, 'Activity theory: A well-kept secret', in Y. Engeström et al. (eds.), Perspectives on activity theory, pp. 1-18, Cambridge University Press, Cambridge. http://dx.doi.org/10.1017/CBO9780511812774.002

Esambe, E.E., 2015, 'Formative feedback and essay writing practices for at-risk students', Unpublished MEd dissertation, Cape Peninsula University of Technology, Cape Town, South Africa.

Fairclough, N., 2005, 'Discourse analysis in organisational studies: The case for critical realism', Organisational Studies 26(6), 915-939. http://dx.doi.org/10.1177/ 0170840605054610

Fisher, D. \& Frey, N., 2009, 'Feed up, back, forward', Educational Leadership 67(3), 20-25.

Galtung, J., 1975, Peace: research, education, action. Essays in Peace Research, Christian Ejlers, Copenhagen, Vol 1, pp. 273-276.

Gardner, J., 2006, 'Assessment and learning: An introduction', in J. Gardner (ed.), Assessment and learning, pp. 81-101, Sage, London.

Hardman, J., 2005, 'Activity theory as a potential framework for technology research in an unequal terrain', South African Journal of Higher Education 19(2), 378-392.

Harvey, D., 1996, Justice, nature and the geography of difference, Blackwell, Oxford.

Hassan, S., 2013, 'Evaluation of a tutor training programme through the frame of activity theory', in S. Frielick et al. (eds.), Research and development in higher education: The place of learning and teaching, vol. 36, pp. 200-212, Milperra, New South Wales.

Jacobs, C., 2005, 'On being an insider on the outside: New spaces for integrating academic literacies', Teaching in Higher Education 10(4), 475-487. http://dx.doi. org/10.1080/13562510500239091

Jacobs, C., 2007, 'Towards a critical understanding of the teaching of disciplinespecific academic literacies: Making the tacit explicit', Journal of Education 41, s9-82.
Janks, H., 2012, 'The discipline and craft of academic writing: Building writing capacities in institutions of higher education', Reading \& Writing, 3(1), Art \#25, 9 pages. http://dx.doi.org/10.4102/rw.v3i1.25

Katiya, M., Mtonjeni, T. \& Sefalane-Nkohla, S., 2015, 'Making sense of errors made by analytical chemistry students in their writing', Journal of Language Teaching and Research 6(3), 490-503. http://dx.doi.org/10.17507/jltr.0603.04

Klein, B. \& Aller, B.M., 2008, 'Writing across the curriculum in college chemistry: A practical bibliography', Language and Learning Across the Disciplines 2(3), 25-35.

Kuratani, D \& Lai, E., 2011, Team lab - photovoice literature review, (ebook), viewed 4 February 2014, from http://teamlab.usc.edu/Photovoice\%20Literature\%20 Review\%20(FINAL).pdf

Lea, M.R. \& Street, B.V., 2006, 'The 'academic literacies' model: Theory and applications', Theory into Practice 45(4), 368-377. http://dx.doi.org/10.1207/ s15430421tip4504_11

Letherby, G., 2006, 'Emancipatory research', in V. Jupp (ed.), The SAGE dictionary of social research methods, SAGE Publications, London. http://dx.doi.org/10.4135/ 9780857020116.n62

Makoelle, T.M., 2010, 'Action research: A tool for stimulating reflection and innovation among teacher researchers', in D. Francis et al. (eds.), Praxis towards sustainable empowering learning environment in South Africa, pp. 27-41, Sun Press, Bloemfontein.

Makoelle, T.M., 2012, 'Analysing the use of action research to develop practices of inclusion: A case of a South African school', Journal of. Sociology and Social Anthropology 3(2), 83-91.

Mathew, C. \& Sternberg, R., 2009, 'Developing experience-based (tacit) knowledge through reflection', Learning and Individual Differences 19(4), 530-540. http:// dx.doi.org/10.1016/j.lindif.2009.07.001

McKenna, S., 2004, 'A critical investigation into the discourses used to construct Academic Literacy at the Durban Institute of Technology', Published PhD study, Rhodes University.

McKenna, S., 2010, 'Cracking the code of academic literacy: An ideological task', in C. Boughey et al. (eds.), Beyond the university gates: Provision of extended curriculum programmes in South Africa, Proceedings of the January 2009 Rhodes University Foundation Seminar.

Neuman, W.L., 2000, Social research methods: Qualitative and quantitative approaches, Allyn \& Bacon, Boston.

Paxton, M., 2004, Intertextuality in student writing: The intersection of the academic curriculum and student voices in first year economics assignments', Unpublished doctoral dissertation, University of Cape Town, South Africa.

Paxton, M., 2007, 'Students' interim literacies as a dynamic resource for teaching and transformation', Southern African Linguistics and Applied Language Studies 25(1), 45-55. http://dx.doi.org/10.2989/16073610709486445

Paxton, M., 2012, 'Student voice as a methodological issue in academic literacies research', Higher Education Research \& Development 31(3), 381-391. http:// dx.doi.org/10.1080/07294360.2011.634382

Porpora, D.V., 1998, 'Four concepts of social structure', in M. Archer et al. (eds.), Critical realism: Essential readings, pp. 339-355, Routledge, London.

Pryor, J. \& Crossouard, B., 2010, 'Challenging formative assessment: Disciplinary spaces and identities', Assessment and Evaluation in Higher Education 35(3), 265-276. http://dx.doi.org/10.1080/02602930903512891

Sayer, A., 2000, Realism and social science, Sage, London. http://dx.doi.org/10.4135/ 9781446218730

Shay, S., 2008, 'Researching assessment as social practice: Implications for research methodology', International Journal of Educational Research 47, 159-164. http:// dx.doi.org/10.1016/j.ijer.2008.01.003

Shute, V., 2008, 'Focus on formative feedback', Review of Educational Research 78(1), 153-189. http://dx.doi.org/10.3102/0034654307313795

Swantz, M.L., 2008, Participatory action research as practice, in The SAGE handbook of action research: Participative inquiry and practice, 2 nd edn., pp. 31-40, SAGE Publications Ltd, London. http://dx.doi.org/10.4135/9781848607934.n8

Tolman, C.W., 1999, 'Society versus context in individual development: Does theory make a difference?', in Y. Engeström et al. (eds.), Perspective on activity theory, pp. 70-86, Cambridge University Press, Cambridge. http://dx.doi.org/10.1017/ CBO9780511812774.007

Vygotsky, L.S., 1978, Mind in society: The development of higher psychological processes, Harvard University Press, Cambridge.

Wheelehan, L., 2007, 'Blending activity theory and critical realism to theorise the relationship between the individual and the society and the implications for pedagogy', Studies in the Education of Adults 39(2), 183-196.

Winberg, C., van der Geest, T., Lehman, B. \& Nduna, J., 2010, 'Teaching technical writing in multilingual contexts: A meta-analysis', Southern African Linguistics and Applied Language Studies 28(3), 299-308. http://dx.doi.org/10.2989/16073614.2 010.545032 